\title{
Afterword: new horizons in materiality and literature
}

\author{
Simon C. Estok ${ }^{1,2}$
}

Accepted: 20 October 2020 / Published online: 18 November 2020

(c) Akadémiai Kiadó, Budapest, Hungary 2020

\begin{abstract}
This article is an afterword (in every sense of that word) on a special collection about "materiality and literature." It follows up on a promise that Thomas Bremer makes at the end of the Introduction to the special issue, where he acknowledges that there are "new horizons" waiting to be explored in theorizing about the topic. Most prominently visible on these new horizons, but not mentioned in the articles themselves, is what has been called "the new materialism." This article explores very briefly the contributions of this burgeoning field, touching on matters relating with the current Covid-19 pandemic, climate change, and the state of the humanities itself.
\end{abstract}

Keywords New materialism · Agency $\cdot$ Material entanglement $\cdot$ Genetic materialism

Thomas Bremer ends his elegant introduction to this special issue on "Materiality and literature" by speaking of how "the materiality of and in literature [... is] opening new horizons in comparative literary studies," and it is these new horizons with which I must begin this Afterword. On the new horizons of which Bremer speaks is what has been called the "New Materialism." It is an area that has developed a very large body of scholarship in a very short period of time. The enormity of scholarship over the past fifteen years or so in this area demands attention. There are several reasons for this. One of the most obvious of these is that because so much of the work in the New Materialism is necessarily inter- and transdisciplinary, comparative literary studies simply cannot afford to ignore it. Equally important is that much of this work engages with (and forces literary studies to engage with) what is perhaps the most pressing of material crises humanity has ever faced: climate change. Climate change

\footnotetext{
${ }^{1}$ I use the singular (the New Materialism) throughout to specify a broad field of study rather than to imply that there is a single new materialism. There are indeed many new materialisms in this original and developing area of scholarship.
}

Simon C. Estok

estok@skku.edu

1 Sichuan University, Chengdu, China

2 Sungkyunkwan University, Seoul, Republic of Korea 
is actually a set of crises, and these crises now determine what Bremer describes as the materiality in literature (a thematic issue) and the materiality of literature (relations, materials, means, and modes of production). The New Materialism is a movement away from what Bremer describes as a "more hermeneutical proceeding" to a recognition of what Jane Bennett has called "a political ecology of things." is a movement toward a kind of scholarship that is more actively engaged with the materials of the world, perhaps a bit further away from the oft-pilloried Ivory Tower than is abstract theorizing. Indeed, the New Materialism is a response to a felt need for engagement with the materiality of the world: "normative theory itself," Diana Coole and Samantha Frost explain, "needs to become more engaged with the changing material context in which it considers concepts such as social justice" (Coole and Frost 2010, p. 21). The New Materialism is an important development within academia toward an activist theorizing, congruent and often intersecting with other activist theories (historical materialism, feminism and material feminisms, ecocriticism, and so on). In an age when academia is losing funding and popular traction to the more "useful" and marketable business and technology-oriented degree programs, abstract and politically disengaged theorizing may not be a part of the most hopeful future. The New Materialism, because of its direct engagement and grapplings with real world problems, may very well be a lifeline that the Humanities so desperately need.

In their introduction to the edited collection entitled New Materialisms: Ontology, agency, and politics, Diana Coole and Samantha Frost explain that "everywhere we look, $[\ldots]$ we are witnessing scattered but insistent demands for more materialist modes of analysis and for new ways of thinking about matter and processes of materialization" (ibid, p. 2). Among the main reasons we are witnessing these demands is that matter has too long been ignored. Thus, for Christopher Gamble, Joshua Hanan and Thomas Nail, a "common motivation for the 'materialist turn' is a perceived neglect or diminishment of matter in the dominant Euro-Western tradition as a passive substance intrinsically devoid of meaning" (Gamble et al. 2019, p. 111). So, new ways of thinking are coming. In order for them "to succeed," Coole and Frost argue, "a reprisal of materialism must be truly radical" (Coole and Frost 2010, p. 3). What we have witnessed in part in Coole and Frost's collection, and in part in the work that built up to it, is precisely such radical reprisals.

The New Materialism does not have a single source but arises independently among a variety of scholars at roughly the same time and in response to an emphasis within critical theory on social constructionism and what Stacy Alaimo and Susan Hekman call "an impasse caused by the contemporary linguistic turn in feminist thought" (Alaimo and Hekman 2008, p. 1). It is, Rick Dolphijn and Iris van der Tuin note, "by nature a feminist project" (Dolphijn and van der Tuin 2012, p. 93), and the initial and most influential work has come primarily (but not solely) from feminist theorists. Rosi Braidotti, Elizabeth Grosz, Jane Bennett, Vicki Kirby, Stacy Alaimo, Susan Hekman, Diana Coole, and Samantha Frost are foremost among these (see References for extensive list of relevant readings).

\footnotetext{
${ }^{2}$ The phrase comes from the subtitle of Bennett's book Vibrant matter.
} 
While a lot of the theorizing about the new materialism has come from social theorists and scholars in the humanities, some of the most significant work has come from an entirely different discipline: theoretical physics - an unexpected source, perhaps, but a logical one, given the topic. Indeed, to engage in any kind of materialist theories without engaging with the topic of materials seems somewhat absurd. While I certainly do not mean to malign any of the authors of this special issue, and while all of the articles are excellent at what they address, none of the theories covered in this special issue actually deals with material in ways that recognize the theoretical implications of the four basic materials we find in our world: solid, liquid, gas, and plasma. Nor do the theories of this special issue recognize (or theorize about the importance of) the variation of materials in the natural state of solids: there are amorphous solids, crystalline solids, plastic crystals, and quasi-crystals. Liquid can be liquid crystals and non-Newtonian fluids. Outside of their natural states, there are many other forms of matter: supercritical fluid, degenerate matter, electron-degenerate matter, neutron-degenerate matter, strange matter, quantum spin Hall state matter, Bose-Einstein condensates, fermionic condensates, superfluids, supersolids, quantum spin liquids, heavy fermion materials, string-net liquids, dropletons, Jahn-Teller metals, time crystals, Rydberg polarons, Rydberg matter, quark-gluon plasma, color-glass condensate, and so on. To engage in material theories surely must mean to engage with these realities. Surely, moreover, this is one of Bremer's new horizons. Indeed, among the most influential work in the New Materialist movement has been that from theoretical physics. Karen Barad has led the way. One of the key arguments (and a paradigm changer) that she has made is that

The very nature of materiality is an entanglement. Matter itself is always already open to, or rather entangled with, the "Other." The intra-actively emergent "parts" of phenomena are co-constituted. Not only subjects but also objects are permeated through and through with their entangled kin; the other is not just in one's skin, but in one's bones, in one's belly, in one's heart, in one's nucleus, in one's past and future. This is as true for electrons as it is for brittlestars as it is for the differentially constituted human [...]. What is on the other side of the agential cut is not separate from us-agential separability is not individuation. Ethics is therefore not about right response to a radically exterior/ized other, but about responsibility and accountability for the lively relationalities of becoming of which we are a part (Barad 2007, pp. 392-393.)

The notion of entanglement is profoundly important, worth quoting at length from Barad:

To be entangled is not simply to be intertwined with another, as in the joining of separate entities, but to lack an independent, self-contained existence. Existence is not an individual affair. Individuals do not pre-exist their interactions; rather, individuals emerge through and as part of their entangled intra-relating. Which is not to say that emergence happens once and for all, as an event or as a process that takes place according to some external measure of space and of time, but rather that time and space, like matter and meaning, come into existence, are iteratively reconfigured through each intra-action, thereby making it 
impossible to differentiate in any absolute sense between creation and renewal, beginning and returning, continuity and discontinuity, here and there, past and future. (Ibid, p. ix.)

It becomes very clear that the New Materialism is more than simply a new category of materialist theorizing: it is a rupture of long-standing ontological and epistemological paradigms that are founded on the notions that nonbiotic material lacks agency, that human life is entitled to a unique kind of ethical consideration, and that materials exist independently of other materials.

The New Materialism is a movement that "dislocates agency as the property of a discrete, self-knowing subject inasmuch as the corpus is now recognized as exhibiting capacities that have significant effects on social and political situations" (Coole and Frost 2010, p. 20). It is a movement that recognizes agency within materials outside of the human. Chad Shomura explains that "New materialisms reject fantasies of human mastery and affirm the entanglement of humans with nonhuman animals, vegetables, and minerals." 3 Thus, again to cite Coole and Frost, "one of the most distinctive characteristics of the new materialist ontologies [is] their avowed posthumanism" (ibid.). This builds on Barad's argument that

In an agential realist account, agency is cut loose from its traditional humanist orbit. Agency is not aligned with human intentionality or subjectivity. Nor does it merely entail resignification or other specific kinds of moves within a social geometry of anti-humanism. The space of agency is not only substantially larger than that allowed for in Butler's performative account, for example, but also, perhaps rather surprisingly, larger than what liberal humanism proposes. Significantly, matter is an agentive factor in its iterative materialization. (Barad 2007, pp.177-178.)

For New Materialists, agency is an inherent aspect of materials themselves and is not the sole domain of the human, and there is a lot at stake in such a radical proposition. Indeed, as they explain, "what is at stake here is nothing less than a challenge to some of the most basic assumptions that have underpinned the modern world, including its normative sense of the human and its beliefs about human agency, but also regarding its material practices such as the ways we labor on, exploit, and interact with nature" (ibid, p. 4).

It is not a new materialism in that it absolutely rejects the old and proposes an entirely novel set of alternatives. Dolphijn and van der Tuin explain that "New materialism does not intend to add yet another specialized epistemology to the tree of academic knowledge production" and "is not necessarily different from any other materialist, pragmatic or monist tradition either, since it carefully 'works through' all these traditions in order to avoid, along with the trap of antagonism, the trap of anachronism;" rather "New materialism says 'yes, and' to all of these intellectual traditions, traversing them all, creating strings of thought that, in turn, create

\footnotetext{
3 See "Exploring the promise of New Materialisms" https://csalateral.org/issue/6-1/forum-alt-humanities -new-materalist-philosophy-promise-new-materialisms-shomura/\#fn-1737-4.
} 
a remarkably powerful and fresh 'rhythm' in academia today" (Dolphijn and van der Tuin 2012, p. 89). One of the consequences of these new conceptualizations of materials and their dynamics is a new understanding of narrative itself.

We can understand matter as being "storied," a concept that Serenella Iovino and Serpil Oppermann explore and expand upon in their introduction to Material ecocriticism. They explain that "meanings, stories, signs, and discourses are embedded in material forms, intra-acting with the lives and landscapes of humans and nonhumans" (Iovino and Oppermann 2014, p. 13) and that there is "a material 'mesh' of meanings, properties, and processes, in which human and nonhuman players are interlocked in networks that produce undeniable signifying forces" (ibid, pp. 1-2). In her entry entitled "Storied matter" in the Posthuman glossary, Oppermann cites cosmologists Brian Swimme and Mary Evelyn Tucker as observing that "the universe is not simply a place but a story-a story in which we are immersed, to which we belong, and out of which we arose" (Swimme and Tucker 2011, p. 2, as cited by Oppermann 2018, pp. 411-412). Oppermann explains that "Storied matter compels us to think beyond anthropocentricity and about our coexistence and coevolution in the story of the earth itself" (Oppermann 2018, p. 412). When Jeffrey Jerome Cohen explains that "Storied matter is thick with surprising narratives" (Cohen 2015, p. 275), we may understand that it is not just stories that we have but storeys of stories embedded in objects. Matter is layered with narratives. Iovino and Oppermann explain that this has profound implications for how we conceptualize and imagine categories of the world:

The new materialist thinkers invite us to reconsider the categories of the world. Their main claim is that discourses about the living world, though necessary, are per se insufficient, if separated from their broader material substratum of inanimate substances and apersonal agencies. In other words, not everything that happens in this world and interferes with living systems is "alive" in the biological sense. Agency assumes many forms, all of which are characterized by an important feature: they are material, and the meanings they produce influence in various ways the existence both of human and nonhuman natures. Agency, therefore, is not to be necessarily and exclusively associated with human beings and with human intentionality, but is a pervasive an inbuilt property of matter, as part and parcel of its generative dynamism. From this dynamism, reality emerges as an intertwined flux of material and discursive forces, rather than as [a] complex of hierarchically organized individual players. (Iovino and Oppermann 2014, p. 3.)

Now more than ever, these issues of the New Materialism are imperative.

Entering the third decade of the twenty-first century, we have been reminded perhaps like never before of just how much a mistake it is to ignore the impacts of materiality and nonhuman material agencies on our daily lives. Climate change realities, which had begun to receive long-overdue mass media attention until 2020, suddenly became low on the list of priorities in the public imagination, with the staggering material realities of the Covid-19 pandemic trumping virtually everything else in our day-to-day lives. The agency of a microscopic material would bring the airline industry to its knees, cost the world trillions of dollars in losses, 
infect and kill millions of people, and produce untold numbers of unknown effects. Granted that most of the articles in this special issue were conceived of and written before Covid-19, it seems necessary here at least to mention that genetic materialism (one of the manifestations of new materialist thinking) is germane today in ways that simply could not have been predicted before Covid-19.

Yet, the topic certainly had been receiving attention before the Covid-19 pandemic. In his influential Literary Darwinism, Joseph Carroll has argued that "no reputable psychologist or anthropologist can ignore the findings of biologically oriented study, and even sociologists and political scientists will have to accommodate themselves to the reality of what is empirically known about the biological basis of human behavior" (Carroll 2012, p. x). Helen Feder, in her book entitled Ecocriticism and the idea of culture: Biology and the bildungsroman, talks about "the cogent reality of materiality, [...] an agential world apart from human culture," of how "the need for a more biologically, ecologically informed critique is, if anything, now more urgent" than ever (Feder 2014, p. 1). Feder goes on to explain that "by turning to biology, cultural biology, and related branches of the life sciences, we find the broader and more nuanced notion of culture necessary for a materialist ecocritical perspective" (ibid.). Feder proposes an "ecocultural materialist" approach (ibid, p. 2). Published in 2014, the same year as the important Iovino/Oppermann collection entitled Material ecocriticism, Feder's book is an explicitly materialist ecocritical inquiry that references and builds on the work done in the field to that date. The strength and value of these works at least in part resides in the persistent attention they pay to questions about agency and to questions about agency beyond the human-or what David Abram has called the "more-than-human" (Abram 1996, p. 15). Much of this agency is in genetic material. ${ }^{4}$

The new materialism recognizes the importance of genes to questions about agency. Famed entomologist E.O. Wilson speaks directly to the question about relationships between genes and agency:

[...] genes hold culture on a leash. The leash is very long, but inevitably values will be constrained in accordance with their effects on the human gene pool. The brain is a product of evolution. Human behavior-like the deepest capacities for emotional response which drive and guide it-is the circuitous technique by which human genetic material has been and will be kept intact. Morality has no other demonstrable ultimate function. (Wilson 1978, p. 167.)

Haruki Murakami puts it more forcefully in his epic novel 1Q84:

Human beings are ultimately nothing but carriers-passageways-for genes. They ride us into the ground like racehorses from generation to generation. Genes don't think about what constitutes good or evil. They don't care whether

\footnotetext{
${ }^{4}$ Part of this paragraph appears in slightly different form in my 2018 monograph The ecophobia hypothesis (Estok 2018, pp. 25-26) and in my "Material ecocriticism, genes, and the phobia/philia spectrum" (Estok 2017, p. 304).
} 
we're happy or unhappy. We're just means to an end for them. The only thing they think about is what is most efficient for them. (Murakami 2011, p. 269.)

Richard Dawkins puts it even more succinctly: "genes [...] we are their survival machines" (Dawkins 2016, p. 25). However we word it, the thought is terrifying: our sense of agency is overblown. This is perhaps the single, most important insight of New Materialist thinking, and it has profound implications for how we think about materials and how they matter.

This special issue on materialism, broadly speaking, opens onto vast horizons for future cutting-edge research. Ultimately, Bremer is right: there are new horizons waiting to be explored. This exploration has already begun, excitingly. In a time such as ours when our survival is by no means a guarantee, a time at which a global pandemic continues to rage and economies continue to stagger, New Materialist theorizing has a lot to offer.

Acknowledgements This work was supported by the double-first class discipline cluster "The Chinese Language and Literature and the Global Dissemination of Chinese Culture," Sichuan University, China.

\section{References}

Abram, D. (1996). The spell of the sensuous: Perception and language in a more-than-human world. New York: Vintage.

Alaimo, S., \& Hekman, S. (2008). Introduction: Emerging models of materiality in feminist thought. In S. Alaimo \& S. Hekman (Eds.), Material feminisms (pp. 1-19). Bloomington and Indianapolis: Indiana University Press.

Barad, K. (2007). Meeting the universe halfway: Quantum physics and the entanglement of matter and meaning. Durham: Duke University Press.

Bennett, J. (2010). Vibrant matter: a political ecology of things. Durham: Duke University Press.

Braidotti, R. (1991). Patterns of dissonance: a study of women and contemporary philosophy. Cambridge: Polity Press.

Braidotti, R. (1994). Nomadic subjects: embodiment and sexual difference in contemporary feminist theory. New York: Columbia University Press.

Braidotti, R. (2000). Teratologies. In I. Buchanan \& C. Colebrook (Eds.), Deleuze and feminist theory (pp. 156-172). Edinburgh: Edinburgh University Press.

Braidotti, R. (2002a). Metamorphoses: Towards a materialist theory of becoming. Cambridge: Polity Press.

Braidotti, R. (2002b). Identity, subjectivity, difference: A critical genealogy. In G. Griffin \& R. Braidotti (Eds.), Thinking differently: A reader in european women's studies (pp. 158-180). London and New York: Zed Books.

Braidotti, R. (2006). Transpositions: On nomadic ethics. Cambridge: Polity Press.

Braidotti, R. (2008). In spite of the times: The postsecular turn in feminism. Theory, Culture and Society, 25(6), 1-24.

Braidotti, R. (2011a). Nomadic theory: The portable Rosi Braidotti. New York: Columbia University Press.

Braidotti, R. (2011b). Nomadic subjects: Embodiment and sexual difference in contemporary feminist theory (2nd ed.). New York: Columbia University Press.

Carroll, J. (2012). Literary darwinism: Evolution, human nature, and literature. New York: Routledge.

Cohen, J. J. (2015). Stone: An ecology of the inhuman. Minneapolis: University of Minnesota Press.

Coole, D., \& Frost, S. (2010). Introducing the new materialisms. In D. Coole \& S. Frost (Eds.), New materialisms: Ontology, agency, and politics (pp. 1-43). Durham: Duke University Press. 
Dawkins, R. (2016). The selfish gene: $40^{\text {th }}$ anniversary edition. Oxford: Oxford University Press.

Dolphijn, R., \& van der Tuin, I. (2012). A new tradition in thought. In R. Dolphijn \& I. van der Tuin (Eds.), New materialism: Interviews and cartographies (pp. 85-92). Ann Arbor: Open Humanities Press.

Estok, S. C. (2017). Material ecocriticism, genes, and the phobia/philia spectrum. Neohelicon: Acta comparationis litterarum universarum, 44(2), 297-313.

Estok, S. C. (2018). The ecophobia hypothesis. New York: Routledge.

Feder, H. (2014). Ecocriticism and the idea of culture: Biology and the bildungsroman. Farnham and Burlington: Ashgate.

Gamble, C. N., Hanan, J. S., \& Nail, T. (2019). What is new materialism. Angelaki Journal of the Theoretical Humanities, 24(6), 111-134.

Grosz, E. (1994a). A thousand tiny sexes: Feminism and rhizomatics. In C. V. Boundas (Ed.), Gilles Deleuze and the theatre of philosophy (pp. 187-210). London and New York: Routledge.

Grosz, E. (1994b). Volatile bodies: Toward a corporeal feminism. Sydney: Allen and Unwin.

Grosz, E. (2000). Histories of a feminist future. Signs. Journal of Women in Culture and Society, 25(4), 1017-1021.

Grosz, E. (2005). Time travels: Feminism, nature, power. Durham and London: Duke University Press.

Iovino, S., \& Oppermann, S. (2014). Introduction: Stories come to matter. In S. Iovino \& S. Oppermann (Eds.), Material ecocriticism (pp. 1-17). Bloomington and Indianapolis: Indiana University Press.

Kirby, V. (1997). Telling flesh: The substance of the corporeal. New York and London: Routledge.

Kirky, V. (2003). Enumerating language: "The unreasonable effectiveness of mathematics." Configurations, 11(3), 417-439.

Kirky, V. (2006). Judith Butler: Live theory. London and New York: Continuum.

Kirky, V. (2008a). Subject to natural law: A meditation on the "two cultures" problem. Australian Feminist Studies, 23(55), 5-17.

Kirky, V. (2008b). Natural convers(at)ions: or, what if culture was really nature all along? In S. Alaimo \& S. Hekman (Eds.), Material feminisms (pp. 214-236). Bloomington: Indiana University Press.

Kirky, V. (2010). Original science: Nature deconstructing itself. Derrida Today, 3(2), 201-220.

Kirky, V. (2011). Quantum anthropologies: Life at large. Durham and London: Duke University Press.

Murakami, H. (2011). 1Q84: A novel. New York: Alfred Knopf.

Oppermann, S. (2018). Storied matter. In R. Braidotti \& M. Hlavajova (Eds.), Posthuman glossary (pp. 411-414). London: Bloomsbury.

Shomura, C. (2017). Exploring the promise of new materialisms. Journal of the Cultural Studies Association, 6(1) https://csalateral.org/issue/6-1/forum-alt-humanities-new-materalist-philosophy-promi se-new-materialisms-shomura/\#fn-1737-4.

Swimme, B. T., \& Tucker, M. E. (2011). Journey of the universe. New Haven: Yale University Press.

Wilson, E. O. (1978). On human nature. Cambridge and London: Harvard University Press.

Publisher's Note Springer Nature remains neutral with regard to jurisdictional claims in published maps and institutional affiliations. 